\title{
PERMASALAHAN BANGSA DALAM PERSPEKTIF ADAB SYED MUHAMMAD NAQUIB AL-ATTAS
}

\author{
Oleh: \\ Akhmad Hasan Saleh \\ Dosen Institut Agama Islam Negeri (IAIN) Kediri \\ jurnalilmiah81@gmail.com
}

\begin{abstract}
Abstrak
Loss of Adab! Kata ini menjadi sangat familiar didengar ditelinga para akademisi yang gemar dengan dunia pemikiran dan pendidikan beberapa tahun belakangan ini. Menurut Prof. Syed Naquib Al-Attas (SMN Al-Attas) bahwa loss of adab adalah akar masalah bangsa saat ini. Prof. Syed Muhamad Naquib AlAttas-lah yang telah mengungkapkan kata ini sebagai inti masalah manusia saat ini. Beliau mengungkap tiga hal yg menjadi akar masalah umat: Pertama adalah Ilmu yg rusak. Kedua, loss of adab (hilangnya adab). Ketiga, kemunculan pemimpin palsu. Hilangnya adab menyebabkan perilaku manusia yang menyimpang dan keluar dari fitrah kemanusiaannya. Hal ini yang menyebabkan munculnya berbagai masalah seperti kemiskinan, pengangguran, kejahatan, kriminalitas, korupsi, bencana alam, dll. Hilangnya adap pada TuhanNya, hilangnya adab pada sesame manusia, hilangnya adab pada orang tua, adab pada alam semestas, adab dalam berbsnis, adab dalam bekerja, dan lain sebagainya.

Prof. Syed M.Naquib al-Attas menyetakan bahwa ini menyebabnya adalah cara pandang yang salah terhadap realitas. Realitas hanya dibatasi pada realitas empiris saja. Ini yang menyebab manusia tidak merasa "diawasi" oleh TuhanNya, tidak merasa bahwa Tuhan itu ada. Realitas yang non-empiris tidak dianggap. Inilah cara pandang realitas yang salah, dan inilah yang menyebabkan loss of adab ini terjadi.

Solusinya adalah ada pada cara pandang (wordview). Al Attas menyatakan bahwa cara pandang, sikap dan etika seorang Muslim dikendalikan oleh pemikirannya dalam memahami realitas di alam ini, baik realitas fisik maupun metafisik. Seorang Muslim yang memiliki visi keakhiratan memiliki perspektif berbeda dengan orang yang bervisi keduniawian semata dalam melihat setiap realitas dalam kehidupan. Dengan cara pandang yang mengedepankan keakhiratan menjadikan manusia lebih beradab. Dan adab didapatkan melalui pendidikan yang benar dan berkurikulum akhirat bukan hanya dunia.
\end{abstract}

Keywords: loss of adab, wordview, permasalahan bangsa, dan realitas. 


\section{A. PENDAHULUAN}

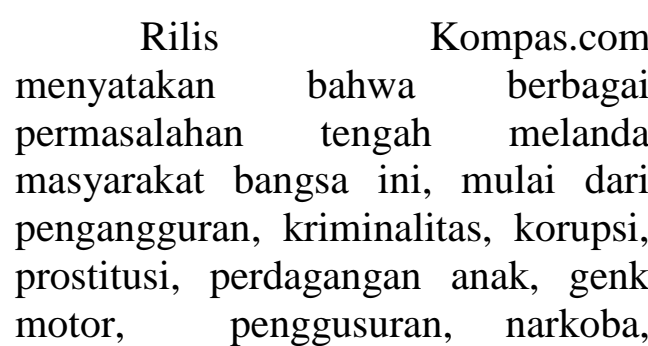
konflik horisontal, terorisme, hingga bencana banjir dan longsor. Para pakar dan ahli telah banyak mengupas masalah itu dengan sudut pandang yang beragam. Jikia dikelompokkan maka ini maka permasalah ini bisa dikelompokkan menjadi lima permasalahan yang menjadi akar pokok penyebab yaitu sistem demokrasi, kesenjangan sosial, pemberantasan korupsi, sistem pendidikan dan pertumbuhan penduduk (kompas.com, 2020)

Hampir mirip dengan yang dirilis Kompas di atas, adalah hasil suvey dari Indo Barometer pada tahun 2019 yang menyatakan bahwa isu ekonomi menjadi masalah paling penting di Indonesia saat ini. Berdasarkan survei Indo Barometer, perekonomian rakyat dianggap oleh 16 persen masyakarakat sebagai masalah utama di Tanah Air. Disusul harga kebutuhan barang pokok dengan 14,6 persen. Sementara isu sosial berupa permasalahan agama dan SARA dipilh oleh 8,3 responden. Survei ini dilaksanakan pada 04-14 Maret 2017 di 34 provinsi di seluruh Indonesia dengan jumlah responden sebesar 1.200 orang. Margin of error yang dipakai sebesar $\pm 3,0 \%$ pada tingkat kepercayaan 95. Responden dipilih dengan metode multistage random sampling. Pengumpulan data dengan wawancara tatap muka secara langsung dengan menggunakan kuesioner. Persentase Anggapan Responden Terhadap Permasalahan Indonesia Menurut Survei Indo Barometer 2019.

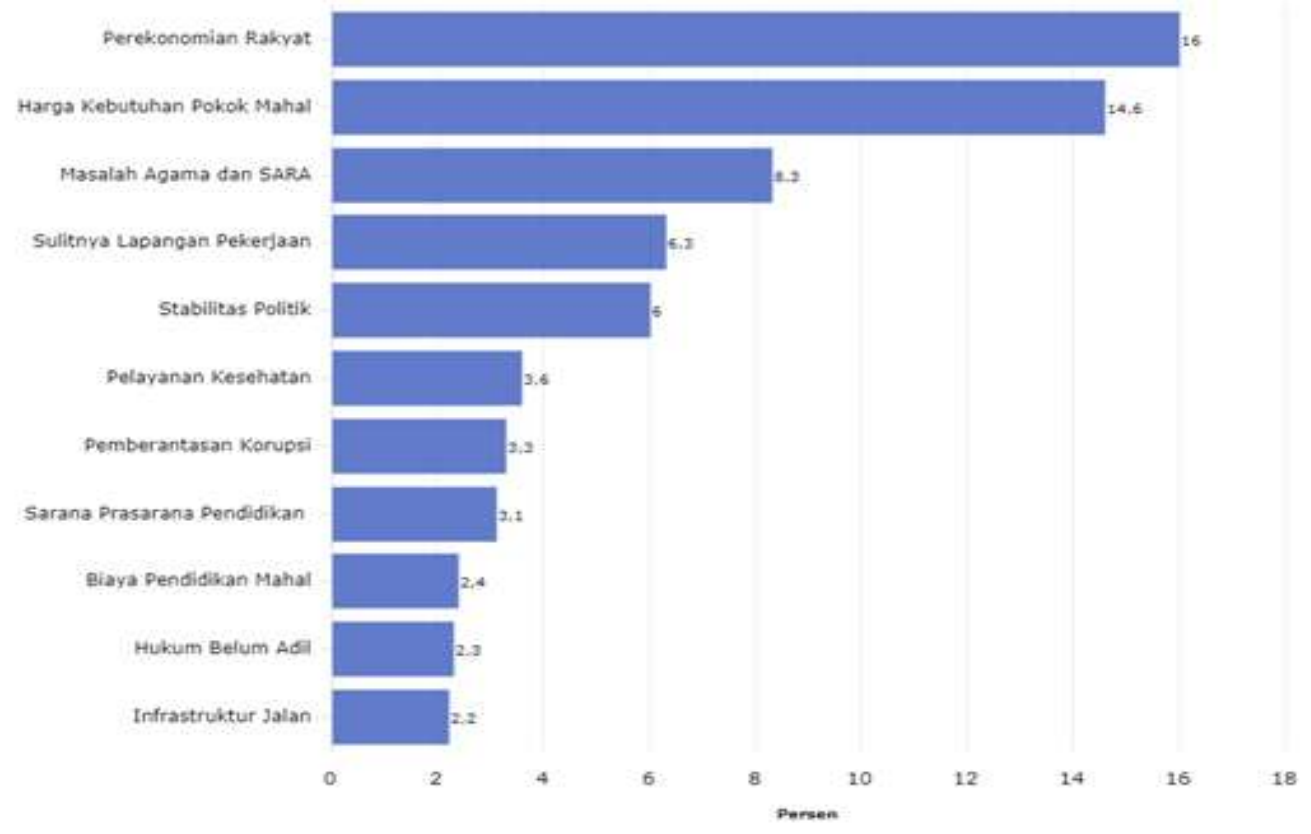

Sumber: data databoks.katadata.co.id (2020) 
Berbagai masalah sosial di atas dapat dicarikan solusinya dengan mendudukan masalah dalam posisi yang tepat. Prof. Syed M.Naquib alAttas telah memberikan sumbangan penting dalam hal ini adalah menata cara pandang yang betul seorang Muslim terhadap realitas.

Cara pandang, sikap dan etika seorang Muslim dikendalikan oleh pemikirannya dalam memahami realitas di alam ini, baik realitas fisik maupun metafisik. Seorang Muslim yang memiliki visi keakhiratan memiliki perspektif berbeda dengan orang yang bervisi keduniawian semata dalam melihat setiap realitas dalam kehidupan. (Alparslan, Islamic Science Towards A Definition, 2000: 29).

Epistemologi Islam sangat berbeda dengan epistemologi Barat yang memandang aktivitas intelektual independen dari hal-hal yang bersifat metafisik. Sebagai contoh, epistemologi kaum empiris yang mendominasi cakrawala manusia Barat di dunia modern telah berhasil mereduksi realitas menjadi sematamata dunia yang dialami oleh indera eksternal, sehingga membatasi makna realitas dan menghilangkan konsep realitas yang mencakup Tuhan. Konsekuensi dari perubahan makna ini telah mereduksi Tuhan dan semua alam spiritual dari 'yang ada' (being) menjadi sesuatu yang abstrak dan pada akhirnya 'tidak nyata' (unreal). ${ }^{1}$

\footnotetext{
${ }^{1}$ Syed Hossein Nasr, The Need for a Sacred Science, hlm. 5
}

Menurut Al-Attas salah solusi dalam memperbaiki adab adalah lewat pendidikan. Pendidikan menjadi benteng harapan terakhir dalam mengatasi solusi permasalahan-permasalahan bangsa ini. Di sisi lain, begitu kompleknya permasalahan-permasalah yang terjadi pada lingkungan sosial kerap memasuki dunia pendidikan. Ketimpangan sosial, berlakunya budaya kekerasan, sifat-sifat individualis, hedonis matrealis serta perilaku-perilaku penyimpangan lainnya yang terjadi di lingkungan sosial masyarakat turut serta mempengaruhi dunia pendidikan. Pilihan antara terlebih dahulu memperbaiki dunia pendidikan agar hadir menjadi solusi bagi masyarakatnya atau memperbaiki lingkungan sosial agar tidak menjadi "virus" bagi pendidikan.

Pendidikan menjadi kian urgen karena berurusan langsung dengan manusia. Manusialah yang berkepentingan mulai dari input, proses sampai output pendidikannya. Manusia menjadi nilai, nilai-nilai kemanusiaan yang berlaku universal tanpa terikat perbedaan bangsa, bahasa, agama untuk mencipta pendidikan berlandaskan manusia. Pendidikan yang memanusiakan. Sekolahnya manusia. Kearah sana manusia berupaya lewat pendidikannya mencipta pemahaman baru yang lebih manusiawi. Sebuah pemahaman akan pendidikan yang mampu menghadirkan manusiamanusia yang baik.

Permasalahan-permasalahan yang terjadi sekarang bisa jadi karena pemahaman yang kurang akan 
pemahaman arti dan makna dari pendidikan itu sendiri. Kekerasan dalam pendidikan, tawuran antar pelajar, bisa jadi manusia produk mesin yang dapat diperjual belikan. Mengungkap makna pendidikan. Upaya pemahaman pendidikan yang lebih memanusiakan mengharuskan pengerahan segala potensi, akal, pikiran, pengamatan, pengalaman serta penelitian yang teruji sehingga dari sana timbul sebuah makna dan pemahaman yang dapat menjadi inspirasi dan motivasi baru untuk bisa lebih proporsional, objektif, serta ilmiah dalam mencermati dan melakukan perilaku-perilaku yang mencerminkan makna pendidikan yang dikehendaki. Upaya pemahaman tentang pendidikan telah melewati catatan sejarah yang panjang. Berbagai teori pendidikan muncul antara pandangan idealism dan realism, antara keturunan hereditas dan lingkungan, antara tabularasa dan pengalaman. Tak pelak lagi pemahaman makna pendidikan dapat merujuk ranah agama. Terlebih Islam sebagai worldview, keuniversalitas ajarannya solusi bagi manusia guna mewujudkan kehidupan bahagia dunia dan akhirat. Banyak para cendekiawan muslim merumuskan konsep pendidikan Islam.

Dalam Islam, istilah pendidikan sering digunakan Tarbiyah dan Ta'lim. Perguruan tinggi Islam yang membuka jurusan keguruan, familiarnya dengan Fakultas Tarbiyah. Penggunaan istilah Tarbiyah dan Ta'lim dirasa kurang mewakili makna pendidikan yang sejatinya, salah seorang ilmuan muslim Syed Naquib al-Attas lebih menyukai penggunaan Ta'dib untuk pendidikan Islam.

Menurut Syed penggunaan Ta'dib untuk pendidikan ini timbul karena dengan berbekal pemahaman yang utuh, komprehensif, tentang pendidikan. Terlebih pemahaman pendidikan yang selaras dengan Islam, dari sana segala hal yang terkait tentang pendidikan, baik Tujuan, strategi, metode dan unsurunsur pendidikan lainnya mencerminkan pandangan pendidikan yang lebih pas dan sesuai seharusnya pendidikan. Dengan penggunaan istilah Ta'dib, Syed Naquib al-Attas berupaya merekonstruksi pemahaman pendidikan yang selama ini terabaikan. Oleh karena ini dalam artikel ini penulis akan membahas tentang "bagaimanakah permasalahan bangsa dalam perspektif adab Syed Muhammad Naquib Al-Attas?"

\section{B. KAJIAN TEORI DAN METODE}

1. Teori

a. Konsep Adab Al-Attas

Gagasan-gagasannya tentang pendidikan Islam dapat kita baca lewat buku Filsafat dan Praktik Pendidikan Islam Syed M. Naquib alAttas karya Wan Mohd Nor Wan Daud. Sebuah buku tentang konsep pendidikan yang ideal. Syed al-attas menekankan Maksud dan tujuan pendidikan bahwa Negara atau pekerja yang baik dalam sebuah Negara sekuler tidak sama dengan manusia yang baik; sebaliknya manusia yang baik sudah pasti seorang pekerja dan warga Negara 
yang baik. Tujuan pendidikan Islam tiada lain menciptakan manusia yang baik.

Penekanan pendidikannya adalah nilai-nilai manusia sebagai manusia sejati, sebagai warga kota, sebagai warga Negara dalam kerajaannya yang mikro, dan sebagai sesuatu yang bersifat spiritual. Pendidikan bukan semata berdasarkan kegunaannya bagi masyarakat, Negara, dan dunia. Nilai manusia yang bukan sebatas entitas fisik yang diukur dalam konteks pragmatis dan utilitarian berdasarkan kegunaannya bagi Negara, masyarakat dan dunia.

Al-Attas mengatakan bahwa orang yang terpelajar adalah orang baik. Dalam artian baik yang menyeluruh, yang meliputi kehidupan spiritual dan material seseorang, yang berusaha menanamkan kualitas kebaikan yang diterimanya. Al-attas menyebut orang yang benar-benar terpelajar menurut persfektif Islam didefinisikan sebagai orang yang beradab.

Dalam uraiannya yang lebih dalam pendidikan menciptakan manusia yang beradab ada dalam pengertian yang komprehensif yang menekankan pada adab. Adab adalah cakupan suatu pengenalan dan pengakuan mengenai tempat secara benar dan tepat, dalam pencapaian kualitas, sifat-sifat, dan perilaku yang baik untuk mendisiplinkan pikiran dan jiwa.

Adab mensyaratkan ilmu pengetahuan dan metode mengetahui yang benar agar mampu menjaga mansuia dari kesalahan. Ilmunya adalah yang dapat mendorong lahirnya perilaku mulia ini adalh kebijaksanaan (hikmah) yang menghasilkan keadilan pada diri individu dan masyarakat serta Negara.

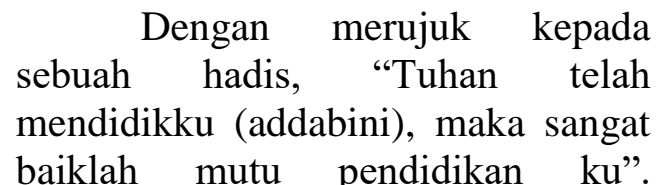
Addabani secara literal berarti telah menanamkan adab pada diriku. Sehingga arti hadis tersebut, "Tuhan telah mendidikku dan menjadikan pendidikanku sebaik-baik pendidikan". Dalam artian hadis yang lebih luas lagi, "Tuhanku telah membuat aku mampu mengenal dan mengakui, dengan adab yang ditanamkan-Nya dalam diriku, tempat-tempat yang tepat bagi segala sesuatu dalam susunan penciptaan, sehingga adab tersebut membawa kepada pengenalan dan pengakuan terhadap tempat-Nya yang sebenarnya dalam susunan being dan eksistensi dan dengan ini Dia menjadikan pendidikan sesuatu yang sangat baik".

Selanjutnya al-Attas mendefinisikan, Adab adalah pengenalan dan pengakuan terhadap realitas bahwasanya ilmu dan segala sesuatu yang ada terdiri dari hirarki yang sesuai dengan kategori-kategori dan tingkatan-tingkatannya, dan bahwa seseorang itu mempunyai tempatnya masing-masing dalam kaitannya dengan realitas tersebut dan dengan kapasitas serta potensi fisik, intelektual dan spiritual. 
Al-Attas menggunakan konsep ta'dib sebagai konsep yang tepat untuk pendidikan Islam, ia lebih lanjut mengatakan, "Struktur konsep ta'dib sudah mencakup unsure-unsur ilmu ('ilm), instruksi (ta'lim), dan pembinaan yang baik (tarbiyah), sehingga tidak perlu lagi dikatakan bahwa konsep pendidikan Islam itu adalah sebagaimana yang terdapat dalam tiga serangkai konotasi tarbiyah-ta'lim-ta'dib".

Menurutnya terminology Ta'dib sendiri sebagai istilah pendidikan telah dipakai oleh para tokoh sufi. Para tokoh sufi yang menonjol dalam pengembangan pribadi Islam melalui pengembangan indera, akal, dan moral. Menggunakan Ta'dib dengan menekankan sebagai bagian daripada proses pendidikan, adab seorang pelajar muslim dan kelompok professional seperti hakim, jaksa, politisi, perwira militer, musikus, guru, dan pelajar menjadi kesatuan yang tak terpisahkan.

Naquib al-Attas mengatakan, setidaknya ada tujuh konsep dalam pendidikan. Pertama, konsep din (agama). Kedua, konsep insan (manusia). Ketiga, konsep ilmu dan makrifat. Keempat, konsep hikmah (kebijakan). Kelima, konsep keadilan. Keenam, konsep amal dan adab. Ketujuh, konsep kuliyyah jami'ah (perguruan tinggi).

\section{Dalam}

Metodologi pendidikan menurutnya memiliki satu tujuan, yakni Islamisasi dari tubuh, pikiran dan jiwa yang berpengaruh pada kehidupan pribadi dan kolektif Muslim serta yang lain, termasuk spiritual dan lingkungan non-fisik manusia.

Al-Attas menulis dalam
bukunya Risalah untuk kaum
Muslimin, "Orang yang baik itu adalah orang yang menyadari sepenuhnya akan tanggung jawab dirinya kepada Tuhan yang haq, yang memahami dan menunaikan kewajiban terhadap dirinya sendiri dan orang lain yang terdapat dalam masyarakatnya, yang selalu berupaya meningkatkan setiap aspek dalam dirinya menuju kearah kesempurnaan sebagai manusia kearah kesempurnaan sebagai manusia yang beradab".

Konsep ta'dib yang diusung oleh Naquib al-Attas ini dapat mudah kita pahami jika kita merujuk pada gagasannya secara keseluruhan. alAttas satu diantara para cendekiawan muslim terkemuka dalam upayanya, Islamisasi ilmu pengetahuan. Baginya Islamisasi sebenarnya berangkat dari asumsi bahwa ilmu pengetahuan itu tidak bebas dari nilai atau netral, sehingga pemahama ta'dib mengajak kita memahami islamisasi ilmu pengetahuan. Al-Attas mengenalkan ta'dib ini sebagai konsep yang asli, integral, komprehensif dan merupakan framework yang kokoh bagi teori dan praktek pendidikan Islam kita.

\section{b. Konsep Wordview}

Pandangan hidup (worldview) merupakan asas dari setiap aktifitas, terutama aktifitas ilmu. Maka, kegiatan pendidikan Islam wajib memiliki landasan Islamic Worldview. Pandangan hidup Islam 
adalah pemahaman seorang Muslim terhadap konsep-konsep kunci dalam Islam, seperti konsep tentang Tuhan, wahyu, nabi, manusia, jiwa, alam, ilmu dan lain-lain

Karena jiwa ilmuan terselimuti oleh adab dan konsepkonsep dasar Islam, maka dalam tradisi ilmu pengetahuan Islam tidak akan ditemuakan penyalahgunaan ilmu untuk tujuan pragmatis, materialis atau tujuan-tujuan lain untuk memuaskan nafsu manusia. Sebab, dalam tradisi Islam, semua ilmu baik ilmu syari'at atau ilmuilmu alam dipelajari dalam rangka pengabdian yang tinggi kepada Tuhan Yang Maha Esa, dan meraih kebahagian sejati. Temuan nuklir contohnya tidak akan digunakan memusnahkan bangsa lain untuk tujuan perluasan daerah kekuasaan. Seorang ahli kedokteran Islam juga tidak akan menggunakan cara-cara haram atau pengobatan yang merugikan.

Dengan bekal dasar worldview Islam serta penguasan komprehensif terhadap konsepkonsep dasar Islam, ilmuan beradab dengan mudah mendeteksi problem yang masuk pada sebuah ilmu. Seoarang ilmuan Muslim beradab mengajarkan dan mempelajari ilmu secara benar dan proporsional. Seorang guru Biologi yang yang beradab memiliki daya nalar kritis yang benar ketika menyampaikan materi teori Darwin kepada siswanya. Bahwa, teori tersebut tidak dibentuk atas dasar keimanan kepada Tuhan. Sehingga dalam temuan teorinya, peran Tuhan 'dipensiunkan' yang berarti bertolak belakang dengan nas- nas al-Qur'ān. Atau dalam studi alQur'ān, ilmuan beradab, pasti akan menolak penyamaan hermeneutika dan ta'wīl. Karena secara konseptual dan asas terbentuknya teori tersebut sama sekali jauh berbeda. Penyaamaan ta'wil dan tafsir dengan hermeneutika berarti menyamakan teks al-Qur'ān dengan teks-teks manusiawi biasa yang tidak memiliki nilai kesucian.

\section{Metode}

Metode penulisan yang dilakukan adalah analisis kritis melalui ekplorasi literature yang berkaitan dengan khasanah pemikiran Al-Attas khususnya tentang adab. Sehingga sumber literature yang digunakan adalah buku, artikel, dan jurnal.

\section{PEMBAHASAN} dituliskan sebelumnya, untuk mengetahui bagaimana mengatasi masalah sosial dengan menegakkan adab sebagai solusinya maka kita harus memahami beberapa hal: 1) esensi adab menurut Prof. SMN AlAttas; dan 2) pendidkan adab.

\section{Esensi $T a$ 'dīb/Adab}

Esensi dari adab menurtut AlAttas adalah bermuara pada makna konsep ta'dī $b$ dibangun dari makna kata dasar adaba dan derivasinya. Kata addaba dan derivasinya, bila maknanya dikaitkan satu sama lain, akan menunjukkan pengertian pendidikan yang integratif ${ }^{2}$. Di antara

\footnotetext{
${ }^{2}$ Lihat Syed Muhammad Naquib al-Attas, Konsep Pendidikan dalam
} 
makna-makna tersebut adalah, yang mengajarkan akhlak, kesopanan, keramahan, dan kesopanan, pengembangan diri atau kehalusan budi pekerti ${ }^{3}$. Makna ini suatu ilmu (ma'rifah) agar anak identik dengan akhlak. Adab juga didiknya terhindar dari kesalahan secara konsisten dikaitkan dengan ilmu, menjadi manusia yang dunia sastra, yakni adab dijelaskan sempurna (insān kāmil) sebagaimana sebagai pengetahuan tentang hal-hal yang indah yang mencegah dari kesalahan-kesalahan ${ }^{4}$. Sehingga seorang sastrawan disebut adīb. Makna ini hampir sama dengan definisi yang diberikan al-Jurjani, yakni ta'dīb adalah proses memperoleh ilmu pengetahuan (ma'rifah) yang dipelajari untuk mencegah pelajar dari bentuk kesalahan $^{5}$.

Kata ta'dīb adalah mashdar dari addaba yang sebenarnya secara konsisten bermakna mendidik. Berkenaan dengan hal itu, seorang guru yang mengajarkan akhlak dan kepribadian disebut juga mu'addib. Setidaknya ada tiga derivasi dari kata addaba, yakni adī $b, t a{ }^{\prime} d \bar{\imath} b$, muaddib. Dari gambaran tersebut dapat dikatakan, keempat makna itu saling terikat dan berkaitan. Seorang pendidik (muaddib), adalah orang

Islam: Suatu Kerangka Pikir Pembinaan Filsafat Pendidikan Islam,terj. (Bandung: Mizan, 1987), hal. 90

3 Ibn Mandzur,Lisān al-'Arabì entri $a-d a-b a$ dan Ibrahim Mustofa (dkk),al-Mu'jam al-Wasīt entri adaba (Istanbul: Maktabah al-Islāmiyah, 1380 H/ 1960 M)

4 Kemas Badruddin, Filsafat Pendidikan, Analisis Pemikiran Syed Naquib al-Attas,(Yogyakarta: Pustaka Pelajar, 2009), hal. 59

${ }^{5}$ Syarif al-Jurjani, Kitāb Ta'rifāt (Beirut: Maktabah Lubnaniyah, 1995), hal. 10

dicontohkan dalam pribadi

Rasulūllah Saw. Dalam hadīth Rasulūllah Saw memakai kata addaba yang bermakna mendidik. Diriwayatkan dari Ibn Mas'ud, Rasulūllah Saw bersabda: "Addaban̄ Rabbì fa ahsana ta'dībi (HR. alSam'ani). Cara mendidiknya perlu dengan menggunakan cara-cara yang benar sesuai kaidah, menarik dan indah - seperti seorang sastrawan yang menyuguhkan kata-kata dengan benar, indah dalam berpuisi.

Berdasarkan hal itu, al-Attas mendefinisikan adab dari analisis semantiknya, yakni, adab adalah pengenalan dan pengakuan terhadap realita bahwasannya ilmu dan segala sesuatu yang ada terdiri dari hirearki yang sesuai dengan kategori-kategori dan tingkatan-tingkatannya, dan bahwa seseorang itu memiliki tempatnya masing-masing dalam kaitannya dengan realitas, kapasitas, potensi fisik, intelektual dan spiritual $^{6}$. Dalam hal ini, al-Attas memberi makna adab secara lebih dalam dan komprehensif yang berkaitan dengan objek-objek tertentu yaitu pribadi manusia, ilmu, bahasa, sosial, alam dan Tuhan ${ }^{7}$. Beradab, adalah menerapkan adab kepada

${ }^{6}$ Wan Mohd Nor Wan Daud, Filsafat dan Praktek Pendidikan Isla, hal. 177

7 Syed Muhammad Naquib alAttas, Risalah Untuk Kaum Muslimin, (Kuala Lumpur: ISTAC, 2001), hal. 47 
masing-masing objek tersebut dengan benar, sesuai aturan.

Pada dasarnya, konsep adab al-Attas ini adalah memperlakukan objek-objek tersebut sesuai dengan aturan, nilai-nilai keimanan, wajar dan tujuan terakhirnya adalah kedekatan spiritual kepada Tuhan. Berkenaan dengan hal ini, maka adab juga dikaitkan dengan syari'at dan Tauhīd. Orang yang tidak beradab adalah orang yang tidak menjalankan syari'at dan tidak beriman (dengan sempurna) ${ }^{8}$. Maka orang beradab menurut al-Attas adalah orang yang baik yaitu orang yang menyadari sepenuhnya tanggung jawab dirinya kepada Tuhan Yang Haq, memahami dan menunaikan keadilan terhadap dirinya dan orang lain dalam masyarakat, berupaya meningkatkan setiap aspek dalam dirinya menuju kesempurnaan sebagai manusia yang beradab $^{9}$.

Makna beradab secara sederhana adalah, tidak berbuat zalim. Maksudnya, orang beradab adalah orang yang menggunakan epistemologi ilmu dengan benar, menerapkan keilmuan kepada objeknya secara adil, dan mampu mengidentifikasi dan memilah pengetahuan-pengetahuan (ma'rifah) yang salah. Setelah itu, metode untuk mencapai pengetahuan itu harus juga benar sesuai kaidah Islam. Sehingga, seorang yang beradab (insān adabi) mengerti tanggung jawabnya sebagai

\footnotetext{
${ }^{8}$ Hāsyim Asyari, Adabu al-Ālim wa al-Muta'allim, (Jombang: Maktabah Turats Islamiy, $1415 \mathrm{H}$ ), hal. 11

${ }^{9}$ Wan Mohd Nor Wan Daud, Filsafat dan Praktik, hal. 174
}

jiwa yang pernah mengikat janji dengan Allāh Swt sebagai jiwa bertauhid $^{10}$. Ikatan janji itu selalu ia aplikasikan dalam setiap aktifitasnya ${ }^{11}$. Oleh sebab itu, istilah yang paling tepat untuk pendidikan Islam menurut al-Attas adalah $t a{ }^{\prime} d \bar{\imath} b$ bukan tarbiyah atau ta'lìm. Term tarbiyah tidak menunjukkan kesesuaian makna, ia hanya menyinggung aspek fisikal dan emosional manusia. Term tarbiyah juga diapakai untuk mengajari hewan. Sedangkan ta'lìm secara umum hanya terbatas pada pengajaran dan pendidikan kognitif. Akan tetapi $t a$ 'd $\bar{l} b$ sudah menyangkut ta'lìm (pengajaran) di dalamnya ${ }^{12}$. Singkatnya, konsep ta'dì $b$ mengandung makna yang lebih komprehensif dan integratif daripada tarbiyah.

Berdasarkan hal itu, maka konsep $t a^{\prime} d \bar{l} b$ merupakan konsepsi pendidikan Islam yang menggunakan pendekatana tawhīdī dan objekobjeknya diteropong dengan pandangan hidup Islami (worldview Islam $)^{13}$. Pendekatan tawhīdī adalah pendekatan yang tidak dikotomis dalam melihat realitas. Menurut al-

$$
\begin{aligned}
& { }^{10} \text { QS. Al-A'raf: } 172 \\
& { }^{11} \text { Lihat Adi Setia, "Special }
\end{aligned}
$$
Feature on the Philosophy of Science of Syed Muhammad Naquib al-Attas" dalam Islam and Science Journal of Islamic Perspective on Science Vol. I. December 2003 No. 2, hal. 172

12 Wan Mohd Nor Wan Daud, Filsafat dan Praktik Pendidikan Islam Syed Muhammad Naquib al-Attas,... hal 180

13 Lihat Syed Muhammad Naquib al-Attas, Progelomena, hal. 2 
Attas, pendidikan Islam bukanlah seperti pelatihan yang akan menghasilkan spesialis. Melainkan proses yang akan menghasilkan individu baik, yang akan menguasai pelbagai bidang studi secara integral dan koheren yang mencerminkan padandangan hidup Islam ${ }^{14}$.

Target yang ingin dicapai
dalam konsep ta'dīb adalah pembentukan manusia sebagai manusia sejati, sebagai warga dari kota yang baik, sebagai sesuatu yang bersifat spiritual. Yang ditekankan alAttas bukanlah nilai manusia sebagai entitas fisik. Tetapi nilai manusia sebagai makhluk fitrah yang beriman kepada Allāh Swt ${ }^{15}$. Mengamalkan iman di setiap kegiatan keilmuannya. Sehingga, penguasaan ilmu-ilmu mesti terselimuti oleh worldview Islam. Karena itu, dalam pandangan al-Attas, pendidikan Islam tidak mengenal dikotomi antara ilmu umum dan ilmu syar'i. Semua ilmu yang dipelajari, baik ilmu matematika, fisika, kimia, biologi, bahasa, sosial dan lain sebagainya, mesti mendapat asupan dengan ilmu syari'at.

Dalam pandangan hidup Islam, aspek duniawi harus dihubungkan dengan cara yang sangat mendalam kepada aspek akhirat, dan aspek akhirat adalah signifikasi yang final. Pandangan hidup Islam terbangun dari jaringanjaringan konsep yang saling terkait

${ }^{14}$ Wan Mohd Nor Wan Daud, Filsafatdan Praktik Pendidikan Islam,... hal. 186

${ }^{15}$ Syed Muhammad Naquib alAttas,Islam and Sekularism, hal. 141 seperti konsep Tuhan, wahyu, manusia, alam, ilmu, agama dan lain sebagainya. Manusia beradab menurut al-Attas adalah manusia yang sadar akan kedudukan dirinya di tengah realitas alam dan harus bisa berbuat selaras dengan ilmu pengetahuan secara positif, terpecaya dan terpuji ${ }^{16}$.

Manusia yang beradab, akan melihat segala persoalan di alam ini dengan kacamata worldview Islam. Worldview Islam menjadi 'pisau' analisa setiap persoalan keduniawiyan. Sebagaimana dinyatakan al-Attas, insān adabi itu harus berbuat selaras dengan ilmu pengetahuan secara positif. Yakni, seorang manusia yang selalu menggunakan epistemologi Islam dalam dialognya dengan realita alam. Individu-individu yang beradab seperti ini adalah berperan penting secara sosial dalam pembentuk sebuah masyarakat beradab.

Masyarakat beradab, adalah masyarakat beriman yang memahami din dengan baik dan benar. Yang menarik di sini adalah korelasi antara kata beradab dan ber-dīn dengan benar. Al-Attas menganalisa, bahwa din berasal dar kata da ya na yang berati berhutang. Derivasi kata itu adalah daynun (kewajiban), daynūnah (hukuman), idānah (keyakinan). Islam sebagai sebuah din mengandung makna dari derivasi kata-kata tersebut. Yakni, inti berislam adalah kewujudan manusia yang berhutang kepada Tuhan, penyerahan diri manusia kepada

16 Lihat Syed Muhammad Naquib al-Attas, Progelomena 
Tuhan, pelaksanaan kekuasaan pengadilan, dan suatu cerminan dari kecenderungan manusia secara fitrah. Kata-kata tersebut di atas juga berkait dengan kata madinah (kota) yakni kota yang berisi manusia-manusia beragama dengan baik ${ }^{17}$. Dari kata ini juga lahir istilah tamaddun yang diartikan peradaban. Di sinilah kata beradab bertemu dengan kata dīn. Sehingga, bisa dikatakan orang beradab adalah orang yang ber-din, melaksanakan syari'ah, menempati janji primordialnya sebagai jiwa bertauhid - yang secara ringkas dikatakan berworldview Islam.

Dengan demikian, pendidikan Islam yang holistik dengan penerapan dinamisasi konsep fardu 'ain dan fardu kifāyah sangat signifikan menunjang pembaharuan pendidikan yang lebih beradab. Ilmu fardu 'ain adalah ilmu yang wajib bagi tiap-tiap individu Muslim mengetahuinya. Mencakup ilmu yang berkenaan dengan i'tiqūd (keyakinan). Ilmuilmu yang menyelamatkan dari keraguan (syakk) iman. Tujuan ilmu ini untuk menghilangkan kekeliruan iman, dan bisa membedakan antara yang haq dan batil. Dimensi lain dari ilmu fardu 'ain - adalah ilmuilmu yang berkenaan dengan perbuatan yang wajib akan dilaksanakan. Misalnya, orang yang akan berniaga wajib mengetahui hukum-hukum fiqih perniagaan, bagi yang akan menunaikan haji wajib baginya memahami hukum-hukum haji. Dan ilmu-ilmu yang berkaitan dengan persoalan-persoalan yang harus ditinggalkan seperti sifat-sifat

$$
{ }^{17} \text { Ibid,... hal. 42-43 }
$$

tidak terpuji dan lain-lain. Sedang ilmu fardu kifāyah adalah ilmu yang wajib dipelajari oleh sebagian masyarakat Islam, bukan seluruhnya. Dalam fardu kifāyah, kesatuan masyarakat Islam secara bersama memikul tanggung jawab fardu tersebut untuk menuntutnya ${ }^{18}$.

Menurut al-Attas, kekacauan ilmu terjadi ketika seorang pelajar mendapat pengajaran yang tidak tepat mengenai konsep fardu 'ain dan fardu kifāyah. Kesalahan itu terletak pada strategi pembelajaran. Yakni cara mengajarkan ilmu fardu kifāyah yang melepaskan secara total dengan konsepsi ilmu fardu 'ain. Apalagi pengajar-pengajar ilmu fardu 'ain mengkelirukan. Yang terjadi adalah pelajar Muslim mudah digoncangkan adab dan keimanannya ${ }^{19}$.

Dapat disimpulkan, konsep ta'dīb adalah konsep pendidikan yang bertujuan menghasilkan individu beradab, yang mampu melihat segala persoalan dengan teropong worldview Islam. Mengintegrasikan ilmu-ilmu sains dan humaniora dangan ilmu syari'ah. Sehingga apapun profesi dan keahliannya, syar'iah dan worldview Islam tetap masuk dalam dirinya sebagai parameter utama. Individu-individu yang demikian ini adalah manusia pembentuk peradaban Islam yang bermartabat. Dalam tataran praktis, konsep ini memerlukan proses Islamisasi ilmu

18 Abu Hāmid al-Ghazāli, Ihyā' Ulūmuddīn jili I, (Beirut: Dar al-Kutub alIlmiyah, tanpa tahun), hal. 30

${ }^{19}$ Syed Muhammad Naquib alAttas, Risalah Untuk Kaum Muslimin, ... hal. 135 
pengetahuan terlebih dahulu. Karena, untuk mencapai tujuan utama konsep pendidikan ini, ilmu-ilmu tidak hanya perlu diintegrasikan akan tetapi, ilmu yang berparadigma sekuler harus diislamkan basis filosofisnya.

Al-Attas mengatakan tujuan Islamisasi Ilmu Pengetahuan adalah melindungi orang Islam dari ilmu yang sudah tercemar yang menyesatkan dan menimbulkan kekeliruan ${ }^{20}$. Dalam pandangan Syed Al-Attas, ilmu modern banyak yang telah westernized (terbaratkan) yang bangunan konsep-konsepnya disusun ilmuan Barat sekuler. Westernisasi ilmu bukan dibangun di atas Wahyu dan kepercayaan agama, tetapi dibangun di atas tradisi budaya yang diperkuat dengan spekulasi filosofis yang terkait dengan kehidupan sekular yang memusatkan manusia sebagai makhluk rasional. Akibatnya, ilmu pengetahuan dan nilai-nilai etika dan moral, yang diatur oleh rasio manusia, berubah terus menerus ${ }^{21}$.

Untuk keperluan itulah mengislamkan pandangan hidup, perlu dipersiapkan generasi yang menguasai basis-basis ilmu ilmu agama. Yang mampu menguasai konsep-konsep Islam, sekaligus bersikap kritis terhadap fenomena ilmu yang berdasarkan epistemologi sekuler. Jika dua konsep itu dikuasai maka pelajar beradab akan mampu melakukan Islamisasi ilmu. Proses islamisasi itu bukan sekedar memasukkan dalil naqli ke dalam sains, akan tetapi yang diislamkan

${ }^{20}$ Syed Muhammad Naquib alAttas, Islam and Secularism, hal. 41

${ }^{21}$ Ibid, hal. 133-135 adalah, basis filosofisnya, metode berpikir, atau konsep yang dianggap menafikan metafisik atau bertentangan dengan konsep-konsep Islam. Dengan begitu, diharapkan proyek islamisasi ilmu pengetahuan ini menegaskan kembali identitas sains Islam, yang telah hilang. Proyek besar tersebut bakal melahirkan disiplin sains beridentitas Islam, seperti ekonomi Islam, Kedokteran Islam, Kimia Islam, Fisika Islam, Psikologi Islam, dan lain sebagainya.

\section{Pendidikan Ta'dib/Adab}

Pendidikan adab kita kenal dengan istilah pendidikan karakter. Pendidikan karakter mengemuka menjadi isu utama di dunia pendidikan saat ini, terlebih di lingkungan Kementerian Pendidikan Nasional. Merujuk UU No. 20/2003 tentang Sisdiknas disebutkan bahwa fungsi pendidikan adalah membentuk watak serta peradaban bangsa, agar menjadi manusia yang beriman dan bertakwa kepada Tuhan Yang Maha Esa, berakhlak mulia. Hal ini bisa jadi sebagai reaksi dan kekhawatiran bersama atas kondisi pendidikan di Indonesia yang justru banyak melahirkan manusia cerdas namun bermoral rendah.

Pendidikan yang menghargai keunikan individu, serta menekankan kesadaran karakter dirinya sebagai manusia. Hal ini sesuai yang ditegaskan Al-Attas dalam Filsafat pendidikannya sangat jelas menekankan kepada pengembangan individu. Individu yang kebersamaan dengan itu sebagai bagian dari sosial dalam upaya pengembangan dirinya. 


\begin{abstract}
Lebih lanjut al-Attas mengatakan, "Ketika kami menyatakan bahwa tujuan dari pada ilmu pengetahuan adalah melahirkan manusia yang baik, bukanlah berarti bahwa kami tidak bermaksud untuk melahirkan masyarakat yang baik, sebab masyarakat adalah terdiri daripada individu, maka melahirkan seseorang akan melahirkan masyarakat yang baik. Pendidikan adalah -pembuat- struktur masyarakat".
\end{abstract}

Al-Attas menekankan pendidikan dalam rangka manusia beradab adalah invidu yang sadar sepenuhnya akan individualitasnya dan sadar akan hubungannya yang tepat dengan dirinya, tuhannya dengan masyarakat dan dengan alam yang nampak maupun yang ghaib.

Al-Attas selanjutnya memberikan ilustrasi betapa Adab hadir dalam berbagai tingkat pengalaman manusia. pertama, Adab terhadap diri sendiri. Bermula ketika seseorang itu mengakui bahwa dirinya terdiri dari dua unsure, yaitu akal dan sifat-sifat kebinatangannya, maka ia sudah meletakkan keduanya pada tempat yang semestinya dan oleh sebab itu dia telah meletakkan dirinya pada tempat yang benar. kedua, adab dalam kontek ilmu, berarti ketertiban budi yang mengenal dan mengakui hirarki ilmu berdasarkan kriteria tentang tingkattingkat keluhurusan dan kemulian. Kita mengenal fardhu 'ayn (kewajiban bagi dirinya) dan fardhu kifayah (kewajiban bagi masyarakat) yang berarti bahwa segala sesuatu yang berisi petunjuk kehidupan jauh lebih mulia dari segala sesuatu yang yang dipakai dalam kehidupan. Sebagai konsekuensinya adab terhadap ilmu pengetahuan akan menghasilkan cara-cara yang tepat dan benar dalam belajar dan penerapan berbagai bidang sains bagi kehidupan. Dengan kerangka ini maka rasa hormat terhadap guru sebagai salah satu wujud langsung dari adab terhadap ilmu pengetahuan. ketiga, adab berkaitan dengan alam, berarti pendisiplinan akal dalam berhubungan dengan susunan tingkatan yang menjadi karakter alam semesta sehingga seseorang itu bisa membuat keputusan yang tepat tentang nilai-nilai yang sejati dari segala sesuatu baik dalam kontesnya sebagai tanda-tanda Tuhan, sumber ilmu pengetahuan dan segala sesuatu yang berguna untuk perkembangan rohani dan jasmani manusia. Adab pada alam dan lingkungan berarti pula bahwa seseorang itu melettakkan tumbuh-tumbuhan, batu-batuan, gunung, sungai, lembah dan danau, binatang dan habitat-habitatnya pada tempat-tempat yang sebenarnya. Keempat, adab terhadap bahasa, berarti pengenalan dan pengakuan adanya tempat yang benar dan tepat untuk setiap perkataan, baik tulisan maupun percakapan sehingga tidak menimbulkan kerancauan dalam makna, bunyi dan konsep. Keempat, adab pada alam spiritual, adab berarti pengenalan dan pengakuan terhadap tingkat-tingkat keluhuran yang menjadi sifat alam spiritual, pengenalan dan pengakuan terhadap berbagai maqam spiritual berdasarkan ibadah, disiplin spiritual dengan benar memprioritas spiritual dan akal dari pada fisik. 
Tak ayal lagi, Konsep ta'dib dalam kontek pendidikan yang baik tidak bisa dilepaskan kemanfaatannya dan sangat berhubungan dengan katakata kunci dalam pandangan hidup Islam, seperti kebijaksanaan (hikmah) dan keadilan (adl), realitas dan kebenaran (haqq). Ta'dib sebagai konsep Pendidikan Islam, pendidikan karakter manusia-manusianya, agar lebih beradab dan manusiawi.

Gagasan-gagasan Naquib alAttas tentang Ta'dib tiada lain konseptualisasi pendidikan Islam. Mempraktikkan gagasan Islamisasi Ilmu pengetahuan dalam pendidikan. Manusia-manusia baik yang layak menghuni bumi. Sebuah upaya mengungkap makna ta'dib bagi pendidikan agar menjadi arah dan bahan dalam rangka membangun pendidikan karakter manusia Indonesia.

Uraian yang lebih rinci tentang konsep adab dalam Islam disampaikan oleh Prof. Naquib alAttas. Menurut Prof. Naquib, adab adalah "pengenalan serta pengakuan akan hak keadaan sesuatu dan kedudukan seseorang, dalam rencana susunan berperingkat martabat dan darjat, yang merupakan suatu hakikat yang berlaku dalam tabiat semesta." Pengenalan adalah ilmu; pengakuan adalah amal. Maka, pengenalan tanpa pengakuan seperti ilmu tanpa amal; dan pengakuan tanpa pengenalan seperti amal tanpa ilmu. "Keduanya sia-sia kerana yang satu mensifatkan keingkaran dan keangkuhan, dan yang satu lagi mensifatkan ketiadasedaran dan kejahilan," demikian Prof. Naquib al-Attas.
Lebih jauh, Prof. Naquib menjelaskan, bahwa jatuh-bangunnya umat Islam, tergangtung sejauh mana mereka dapat memahami dan menerapkan konsep adab ini dalam kehidupan mereka. Lebih jauh, pakar filsafat Islam dan sejarah Melayu ini menjelaskan:

"Ta'rif adab yang dikemukakan di sini dan yang lahir dari pengertian Islam, dengan sendirinya menjelaskan bukan sahaja harus dia itu ditujukan maksud pengenaannya pada bangsa insani belaka; bahkan dia juga harus dikenakan pada keseluruhan alam tabi'i dan alam ruhani dan alam ilmi. Sebab, adab itu sesungguhnya suatu kelakuan yang harus diamalkan atau dilakukan terhadap diri, dan yang berdasarkan pada ilmu, maka kelakuan atau amalan itu bukan sahaja harus ditujukan kepada sesama insani, bahkan pada kenyataan makhluk jelata, yang merupakan ma'lumat bagi ilmu. Tiap sesuatu atau seseorang memiliki hak yang meletakkannya pada keadaan atau kedudukan yang sesuai bagin keperluannya. Ilmulah, dibimbing serta diyakini oleh hikmat, yang memberitahu atau memperkenalkan sehingga ketara tentang hak yang mensifatkan sesuatu atau seseorang itu; dan keadilan pula yang menjelaskan hukum tentang di manakah atau bagaimanakah letak keadaan atau kedudukannya. Apabila faham adab itu dirujukkan kepada sesama insan, maka dia bermaksud pada kesusilaan akhlakiah yang mencarakan kewajiban diri berperangai mengikut keperluan haknya dalam susunan berperingkat 
darjat yang terencana, umpamanya, dalam keluarga, dalam musharakat, dalam berbagai corak pergaulan kehidupan. Apabila dia dirujukkan pada alam ilmi pula, maka dia bermaksud pada ketertiban budi menyesuaikan haknya pada rencana susunan berperingkat martabat yang mensifatkan ilmu; umpamanya pengenalan serta pengakuan akan ilmu bahawa dia itu tersusun taraf keluhuran serta keutamannya, dari yang bersumber pada wahyu ke yang berpunca pada perolehan dan perolahan akal; dari yang fardu ain ke yang fardu kifayah; dari yang merupakan hidayah bagi kehidupan ke yang merupakan kegunaan amali baginya. Dan adab terhadap ilmu itu iaitu mengenali serta mengakui taraf keluhuran serta keutamaan yang terencana pada ilmu, nescaya dapat menghasilkan dalam diri pencapaian yang seksama terhadap meramukan, menurut taraf keperluannya, pelbagai macam ilmu yang membina keadilan dalam diri. Dan keadilan dalam diri itu menyesuaikan haknya pada kewajiban membimbingnya ke arah pengenalan serta pengakuan akan ilmu yang bersumberkan wahyu, yang menyesuaii hak diri jua, dan yang dengannya dapat menjelmakan akibat amali dalam diri sehingga menyelamatkannya dunia-akhirat."22

22 Hadd merupakan definisi yang menspesifikasikan ciri-ciri utama yang membedakan obyek yang didefinisikan dari obyek lainnya. Contohnya adalah 'manusia adalah hewan yang berpikir" (hayawaan naathiq). kemampuan berbicara (nuthq) yang merupakan manifestasi dari daya berpikir itulah yang menjadikan manusia beda dari
Jadi, seperti ditegaskan oleh Prof. Naquib al-Attas, di dalam Islam, konsep "adab" memang sangat terkait dengan pemahaman tentang wahyu. Orang beradab adalah yang dapat memahami dan meletakkan sesuatu pada tempatnya, sesuai dengan harkat dan martabat yang ditentukan oleh Allah. Di dalam Islam, orang yang tidak mengakui Allah sebagai satu-satunya Tuhan, bisa dikatakan tidak adil dan tidak beradab. Sebab, di dalam al-Quran, syirik dikatakan sebagai kezaliman besar, seperti dikatakan Lukman kepada anaknya: "Wahai anakku, janganlah kamu menserikatkan Allah, sesungguhnya syirik adalah kezaliman yang besar." (QS 31:13). Adalah tidak beradab mengangkat derajat makhluk ke derajat al-Khalik. Begitu juga menurunkan derajat alKhalik ke derajat makhluk juga tindakan yang tidak beradab. Orang yang berilmu juga tidak sama derajatnya dengan orang bodoh. Begitu juga orang mukmin, tidak sama derajatnya dengan orang kafir (QS 98; QS 3:110, 119). Jadi, derajat manusia di hadapan Allah SWT tidaklah sama. Derajat seseorang di

spesies-spesies lainnya yang terdapat dalam genus hewan. Sedangkan definisi Rasm adalah definisi yang menerangkan ciri-ciri utama suatu obyek, dan bukan esensi dari obyek tersebut. Contoh, "manusia adalah makhluk yang tertawa". Jika dalam kategori hadd manusia dipisahkan dari jenis hewan lainnya, namun definisi rasm hanya menerangkan salah satu aspek dari manusia. lihat Wan Muhammad Wan Daud, hlm. 143-144 
hadapan Allah tergantung pada keimanan dan ketaqwaannya.

Konsep adab seperti ini sesuai dengan istilah dan tujuan Pendidikan Islam itu sendiri, yaitu ta'dib dan tujuannya adalah membentuk manusia yang beradab (insan adaby). Prof. Naquib al-Attas dalam bukunya, Islam and Secularism, menggariskan tujuan pendidikan dalam Islam tesebut:

"The purpose for seeking knowledge in Islam is to inculcate goodness or justice in man as man and individual self. The aim of education in Islam is therefore to produce a goodman... the fundamental element inherent in the Islamic concept of education is the inculcation of adab...",23

"Orang baik" atau good man, bisa dikatakan sebagai manusia yang memiliki berbagai nilai keutamaan dalam dirinya. Dengan berpijak kepada konsep adab dalam Islam, maka "manusia yang baik" atau "manusia yang beradab", adalah manusia yang mengenal Tuhannya, mengenal dan mencintai Nabinya, menjadikan Nabi SAW sebagai uswah hasanah, menghormati para ulama sebagai pewaris Nabi, memahami dan melatakkan ilmu pada tempat yang terhormat - paham mana ilmu yang fardhu ain, dan mana yang fardhu kifayah; juga mana ilmu yang bermanfaat dan ilmu yang merusak dan memahami serta mampu

23 Syed Muhammad Naquib al-Attas, Tinjauan Ringkas Peri Ilmu dan Pandangan Alam, Pulau Pinang : Penerbit Universiti Sains Malysia, 2007, hlm. 13, 39 menjalankan tugasnya sebagai khalifatullah fil-ardh dengan baik.

\section{KESIMPULAN}

Dari uraian di atas, dapat disimpulkan bahwa cara agar masalah-masalah kebangsaan dapat selesai dalam perspektif adab AlAttas adalah dengan menegakkan konsep adab dan menariknya dalam dunia empiris melalui pendidikan, dimana pendidikan ini akan bermula dengan memperbaiki wordview melalui pendidkan.

Prof. Syed M.Naquib AlAttas menyatakan bahwa ini menyebabnya adalah cara pandang yang salah terhadap realitas. Realitas hanya dibatasi pada realitas empiris saja. Ini yang menyebab manusia tidak merasa "diawasi" oleh TuhanNya, tidak merasa bahwa Tuhan itu ada. Realitas yang nonempiris tidak dianggap. Inilah cara pandang realitas yang salah, dan inilah yang menyebabkan loss of adab ini terjadi. Solusinya adalah ada pada cara pandang (wordview). Al Attas menyatakan bahwa cara pandang, sikap dan etika seorang Muslim dikendalikan oleh pemikirannya dalam memahami realitas di alam ini, baik realitas fisik maupun metafisik. Seorang Muslim yang memiliki visi keakhiratan memiliki perspektif berbeda dengan orang yang bervisi keduniawian semata dalam melihat setiap realitas dalam kehidupan. Dengan cara pandang yang mengedepankan keakhiratan menjadikan manusia lebih beradab. Dan adab didapatkan melalui pendidikan yang benar dan 
berkurikulum akhirat bukan hanya dunia.

Konsep $t a ' d \bar{\imath} b$ sebagai konsep pendidikan Islam yang digagas Syed Muhammad Naquib Al-Attas merupakan salah satu perwujudan dalam proyek Islamisasi Ilmu pengetahuan. Islamisasi ilmu yang diproyekkan al-Attas adalah pengislaman paradigma ilmu-ilmu yang dianggap sekuler. Proyek ini hanya bisa dilakukan oleh ilmuanilmuan Muslim yang berpandangan hidup Islam dan memiliki dasar-dasar keilmuan Islam yang kuat. Sebab, yang diislamkan dalam proyek ini adalah basis filosofis, yang merupakan elemen dasar sebuah ilmu, bukan produk ilmu. Dengan cara mengeluarkan penafsiran ilmu dari ideologi, makna dan ungkapan sekuler. Konsep ta'dīb al-Attas dalam rangka untuk mencapai tujuan tersebut.

Maka, gagasan al-Attas tentang konsep ta'dīb di dunia kontemporer saat ini adalah suatu hal yang perlu disambut positif. Sebab, dunia pendidikan Islam kita belum menemukan bentuk yang ideal untuk mencetak generasi ilmuan muslim unggul yang bisa berbuat banyak dalam kancah dunia. Apalagi, ilmuilmu yang terwesternized menjadi konsumsi publik dunia perlu

\section{Daftar Kepustakaan}

Aly, Hery Noer. Ilmu Pendidikan Islam, Cet. II. Jakarta: Logos Wacana Ilmu, 1999. diislamkan demi menegakkan peradaban Islam yang bermartabat. Dunia pendidikan Islam, sudah saatnya mengkonsentrasikan diri untuk membentuk manusia-manusia yang beradab. Itu hanya bisa dilakukan jika dunia pendidikan mengajarkan ilmu yang benar secara integratif.

Selain itu diperlukan segera desain kurikum pendidikan Islam yang berasaskan dinamisasi konsep fardu 'ain dan fardu kifāyah. Fardu kifāyah berelemen dasar fardhu 'ain, maka dalam pengajaran ilmu-ilmu yang disebut fardu kifāyah tidak melepaskan dari dimensi ketuhanan. Yang berarti, karakter keilmuannya berdasarkan iman. Pendidikan, tidak saja dimodifikasi untuk mengikuti perkembangan zaman, akan tetapi lebih penting lagi, adab dan esensi konsep Islam harus menjadi acuan penyelenggaraan pendidikan Islam. Seiring dengan semakin mengguritanya pemikiran, konsep dan praktik pendidikan sekular, maka worldview Islam dalam pendidikan Islam harus diajarkan. Kebutuhan yang mendesak ini perlu diawali dengan para guru-guru yang belajar worldview Islam. Karena dari landasan ini paradigma pendidikan beradab dapat terlaksana[].

Ashraf, Ali. Horizon Baru Pendidikan Islam, terj. Sori Siregar, cet. I. Jakarta: Pustaka Firdaus, 1989.

Attas (al), Muhammad Naquib (Ed). Aims and Objectives of 
Islamic

Jeddah: King Abdul Aziz University, 1979.

Islam and

Secularism, terj. Karsimo

Djojokusumo. Bandung:

Pustaka, 1981.

. The Concept of

Education in Islam: A

Framework for An

Philosophy of Education.

Kuala Lumpur: Muslim

Youth Movement of

Malaysia (ABIM), 1980.

. Progelomena to the

Metaphysic of Islam an

Exposition of the

Fundamental Element of

the Worldview Islam

. Konsep Pendidikan

dalam Islam: Suatu

Kerangka Pikir

Pembinaan Filsafat

Pendidikan Islam,terj.

(Bandung: Mizan, 1987)

Risalah Untuk

Kaum Muslimin, (Kuala

Lumpur: ISTAC, 2001)

Ernest Gellner, Postmodernism,

Reason and
Religion,(London-New
York: Routledge, 1993)

Azra, Azyumardi. Paradigma Baru

Pendidikan Nasional,

Rekontruksi dan

Demokratisasi. Jakarta:

Kompas, 2002.
Bawani, Imam. Segi-segi Pendidikan Islam. Surabaya: alIkhlas, 1987.

Hamid Fahmy Zarkasyi,Liberalisasi Pemikiran Islam (Gerakan Bersama Missionaris, Orientalis dan Kolonialis),(Ponorogo: CIOS-ISID Gontor, 2008)

Nahlawi (al), Abdurrahman. "Usul alTarbiyah al-Islamiyah wa Asalibiha fi al-Bait wa alMadrasah wa alMujtama",, terj. Shihabuddin.

Pendidikan Islam di Rumah, Sekolah, dan Masyarakat. Jakarta: Gema Insani Press, 1983.

Nata, Abuddin. Paradigma Pendidikan Islam: Kapita Selekta Pendidikan Islam.

Jakarta: Grasindo, 2001. . Pemikiran Para Tokoh Pendidikan Islam, Seri Kajian Filsafat

Pendidikan Islam. Jakarta: PT. Raja Grafindo Persada, 2001.

\begin{tabular}{lll} 
& & Perspektif Islam \\
Tentang Pola Hubungan & Puru-Murid: Studi \\
Pemikiran & \multicolumn{1}{c}{ Tasawwuf Al-Ghazali. } \\
& Jakarta: PT. Raja \\
Grafindo Persada, 2001. & \\
& Tokoh-Tokoh \\
Pembaharuan Pendidikan \\
Islam di Indonesia. \\
Jakarta: PT. Raja \\
Grafindo, 2005.
\end{tabular}


Thomas S. Kuhn, The Structure of Scientific

Revolution,Peran

Paradigma Dalam

Revolusi Sains, terj. (Bandung: Rosdakarya, 2005)

Wan Mohd Nor Wan Daud, Filsafat dan Praktik Pendidikan Islam Syed Muhammad Naquib al-Attas, terj. Hamid Fahmy Zarkasyi dkk (Bandung: Mizan, 2003)

Sukmadinata, Nana Syaodih. Pengembangan

Kurikulum Teori dan Praktek. Bandung: Remaja Rosdakarya, 2001.

Undang-Undang Republik Indonesia No. 20 Tahun 2003 tentang Sistem Pendidikan Nasional Bab
II, Pasal 2. Surabaya: Karina, 2004.

Wan Daud, Wan Mohd. Nor. "The Educational Philosophy and Practice of Syed Muhammad Naquib alAttas", terj. Hamid Fahmy. Filsafat dan Praktik Pendidikan Syed Muhammad Naquib alAttas, Cet. I. Bandung: Mizan, 2005.

Ibn Mandzur,Lisān al-'Arabī entri ada-ba dan Ibrahim Mustofa (dkk),al-Mu'jam al-Wasīţ entri adaba (Istanbul: Maktabah alIslāmiyah, 1380 H/ 1960 M)

Kemas Badruddin, Filsafat Pendidikan, Analisis Pemikiran Syed Naquib al-Attas, (Yogyakarta: Pustaka Pelajar, 2009) 